\title{
Expression and characterization of family 40 Carbohydrate Binding Module (CBM) from Vibrio cholerae Non-O1 sialidase
}

\author{
Gogula Selvi Asang ${ }^{\mathrm{a}}$, Shadariah Mamat ${ }^{\mathrm{a}}$, Nadiawati Alias ${ }^{\mathrm{a}^{*}}$, Asmad Kari ${ }^{\mathrm{b}}$ \\ aschool of Agriculture Sciences and Biotechnology, Faculty of Bioresources and Food Industry, Universiti Sultan Zainal Abidin, Besut Campus, \\ 22200 Besut, Terengganu, Malaysia \\ ${ }^{b}$ School of Animal Science, Aquatic Science and Environment, Faculty of Bioresources and Food Industry, Universiti Sultan Zainal Abidin, \\ Besut Campus, 22200 Besut, Terengganu, Malaysia
}

Received 25th April 2020 / Accepted 9th September 2020

\begin{abstract}
Carbohydrate Binding Module (CBM) is a non-catalytic protein domain found in carbohydrateactive enzyme (glycoside hydrolase) and its role is to bring carbohydrates in close proximity to the enzyme catalytic site for complete hydrolysis. The removal of this CBM from most protein domains often leads to reduced enzyme activity and efficiency. In this study, a gene encoding for family 40 CBM from Vibrio cholerae Non-O1 sialidase was cloned and successfully expressed in E. coli BL21 (DE3) strain. The CBM40 encoded 195 amino acids with 585 bp of nucleotide sequence. The protein was successfully expressed at $18^{\circ} \mathrm{C}$ when induced with $1 \mathrm{mM}$ IPTG. Maximum expression was achieved at 20 hours after post-induction time. For purification of the protein, an anionic denaturing detergent method was used containing 1\% SDS and $0.1 \%$ sarkosyl with gradient affinity elution at $50 \mathrm{mM}$ imidazole concentrations. SDS-PAGE analysis of the purified CBM40 protein displayed a protein band with a molecular mass of $21 \mathrm{kDa}$. Protein characterization showed optimum stability in $100 \mathrm{mM}$ citrate buffer $\mathrm{pH} 5.5$, with the highest $\mathrm{T}_{\mathrm{m}}$ value of $40{ }^{\circ} \mathrm{C}$. The protein was stable between $\mathrm{pH} 5.5-6.2$ and able to retain its activity at $27-56^{\circ} \mathrm{C}$. The addition of $\mathrm{Mn}^{2+}$ and $\mathrm{Mg}^{2+}$ increased the protein melting temperature to $56^{\circ} \mathrm{C}$. Meanwhile, the addition of reagents, such as $1 \%$ SDS and $1 \mathrm{M}$ urea increased the protein melting temperature $\left(\mathrm{T}_{\mathrm{m}}\right)$ to approximately $55^{\circ} \mathrm{C}$. Protein stability can be influenced by many factors, including different buffers, $\mathrm{pHs}$, temperatures, ionic strengths, and chemical reagents used in a study. The optimum characterization conditions established would further lead to the discovery of CBM40 protein true potential in enhancing substrate binding affinity and protein-carbohydrate recognition, which underpins its broad applications in biotechnology and protein engineering fields.
\end{abstract}

Keywords: Carbohydrate Binding Module, sialidase, protein characterization, protein expression, Vibrio cholerae Non-O1

\section{INTRODUCTION}

Bacterial sialidases have been considered as a core enzyme for bacterial infection and reported to execute the virulence mechanism by acting on the glycosidic linkages of the terminal sialic acid residues in glycoconjugates and synthetic substrates (Woo et al., 2011). The initial step for enzymatic activity is the degradation of sialic acids from various glycoconjugates. Sialidases are multimodular enzymes, consisting of ancillary modules secured at the catalytic domain of the proteins. These prominent modules have been identified as Carbohydrate Binding Modules

*Author for correspondence: Nadiawati Alias, School of Agriculture Sciences and Biotechnology, Faculty of Bioresources and Food Industry, Universiti Sultan Zainal Abidin, Besut Campus, 22200 Besut, Terengganu, Malaysia.Email - nadiawati@unisza.edu.my 
(CBMs) (Lis \& Sharon, 1998). CBMs are small monovalent domains that can be found between catalytic modules at the end of $\mathrm{N}$ - or C-termini within proteins and are generally expressible in recombinant systems, thus provide an interesting alternative to lectins (Guillén et al., 2010; Duan et al., 2016).

CBMs are organized into 86 families based on the similarity in their amino acid sequences (http://www.cazy.org). Five CBM families have been recognized as mammalian glycan-binding domains, namely CBM32, CBM40, CBM47, CBM51, and CBM57 (Ribeiro et al., 2016). Within these, the members of CBM40 are known to bind to the $\mathrm{N}$-acetylneuraminic acid (Neu5Ac) (Figure 1), which is located at the N-terminus of GH33 (glycoside hydrolase 33) sialidase from $V$. cholerae (Moustafa et al., 2004; Connaris et al., 2014). One typical sialidase producer is $V$. cholerae which is a causative agent of cholera and found abundantly in marine and freshwater environments (Mandal \& Mandal, 2014). Among over 200 serotypes of Vibrio cholerae species, two strains, which are $\mathrm{O} 1$ and $\mathrm{O} 139$ serotypes produce cholera toxin (CT) and cause cholera disease, while the non-O1/nonO139 strains are restricted to produce CT but may cause sporadic diarrhoea and extraintestinal infections (Finkelstein, 1996; Teh et al., 2012; Tang et al., 2018). In the present study, the researchers report the construction and expression of CBM40 of Vibrio cholerae Non-O1 sialidase, its purification, and characterization. For carbohydrate active domain, such as CBM40, protein characterization profile is a really important aspect to be explored. Generally, most proteins are sensitive to changes in temperature and $\mathrm{pH}$ as they tend to lose their active conformation structure when these conditions are not optimal. Therefore, protein characterization was carried out to screen the optimal condition for temperature, $\mathrm{pH}$, metal ions, and chemical reagents for CBM40 proteins function and stability. Currently, CBMs application has been established in various biotechnology fields and their use as molecular probes, affinity support for protein immobilization and assistance in vitro glyco-catalysed reactions leading to enhanced yields. This is due to the fact that CBMs are independent folding units and therefore can be engineered to bind and detect varieties of carbohydrates besides being stable to function efficiently in chimeric proteins. Therefore, CBMs are excellent model systems to study proteincarbohydrate recognition mechanism and various ligand specificities for many biotechnological applications.

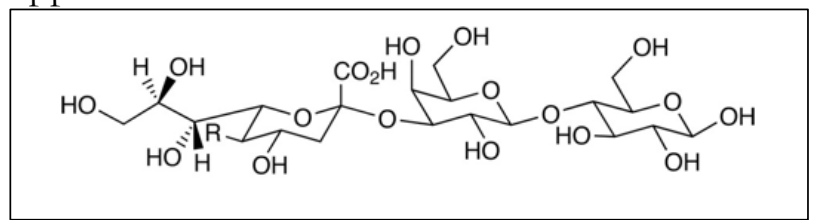

Figure 1. Structure of the 9-carbon monosaccharide, sialic acid or Nacetylneuraminic acids (Neu5Ac). This figure was adapted from Moustafa et al. (2004).

\section{MATERIALS AND METHODS}

\section{Cloning of CBM40 domain and protein expression}

A gene encoding for the CBM family 40 domain from Vibrio cholerae Non-O1 was amplified by the polymerase chain reaction (PCR). The primers used were CBM (F): 5'- GGA TCC ATG CAC TTT TTG ACT ATA ACG C-3', and CBM (R): 5'- GAA TTC GTC GCC TTG AAT TTC AAA C-3' (BamHI and EcoRI restriction sites, as underlined). PCR amplification parameters were performed based on the protocol done by Alias and Mamat (2018). The PCR fragments were purified using QIAquick PCR purification kit (Qiagen), followed by digestion with BamHI and EcoRI before being ligated into digested pET$22 \mathrm{~b}(+)$ vector. The plasmid was transformed into Escherichia coli BL21 (DE3) expression strain and the confirmed colonies were verified by colony PCR. In addition, plasmids were sent for sequencing analysis at $1^{\text {st }}$ Base Laboratory Sdn. Bhd., Malaysia in order to identify positive transformant.

The expression of the CBM family 40 protein was carried out by inoculating the recombinant CBM40 clone into Luria Broth (LB) supplemented with $100 \mu \mathrm{g} / \mathrm{ml}$ ampicillin. The bacteria culture was further incubated at $37{ }^{\circ} \mathrm{C}$ until the OD $\left(\mathrm{A}_{600}\right)$ reached 0.6. Then, the bacterial culture was set to a heat shock stage at $42^{\circ} \mathrm{C}$ for 20 minutes before inducing with $1 \mathrm{mM}$ isopropyl $\beta$-d-1-thiogalactopyranoside (IPTG) followed by overnight incubation at $18^{\circ} \mathrm{C}$. The culture was harvested by centrifugation at 12,000 
rpm for 20 minutes. The cell pellet was kept in sterile tubes and stored at $-80^{\circ} \mathrm{C}$ until further use.

\section{Recombinant protein purification}

The cell pellet was resuspended and lysed in an anionic denaturing buffer, PCL buffer $(2.6 \mathrm{mM}$ $\mathrm{KCl}, 1.4 \mathrm{mM} \mathrm{KH} \mathrm{KO}_{4}, 8 \mathrm{mM} \mathrm{Na} \mathrm{HPO}_{4}, 1 \%$ SDS, $0.1 \%$ sarkosyl, and $286 \mathrm{mM} \mathrm{NaCl}$ at $\mathrm{pH} 7.4$ ) containing protease inhibitors. The cell suspension was sonicated on ice prior to lysis and incubated (on ice) for 30 minutes. The chilled lysates were centrifuged at $40,000 \mathrm{~g}$ for 30 minutes at $4^{\circ} \mathrm{C}$ to remove cell debris. The supernatant was filtered through a Sartorius Minisart ${ }^{\circledR}$ Syringe Filter pore size $0.22 \mu \mathrm{m}$ before being loaded into an affinity column, HisTrap FF (GE Healthcare) connected to AKTA protein purification system (GE Healthcare). The column was equilibrated with PCW buffer $\left(2.6 \mathrm{mM} \mathrm{KCl}, 1.4 \mathrm{mM} \mathrm{KH}_{2} \mathrm{PO}_{4}\right.$, $8 \mathrm{mM} \mathrm{Na} \mathrm{HPO}_{4}, 0.1 \%$ sarkosyl, and $286 \mathrm{mM}$ $\mathrm{NaCl}$ at $\mathrm{pH}$ 7.4) until the flow-through absorption returned to the baseline level. Bound protein was eluted with PCE buffer $(2.6 \mathrm{mM} \mathrm{KCl}, 1.4 \mathrm{mM}$ $\mathrm{KH}_{2} \mathrm{PO}_{4}, 8 \mathrm{mM} \mathrm{Na} \mathrm{HPO}_{4}, 0.1 \%$ sarkosyl, 286 $\mathrm{mM} \mathrm{NaCl}$ at $\mathrm{pH}$ 7.4) with increased concentrations of imidazole from 10-100 mM. Protein fractions were taken at various points and loaded on $12 \%$ SDS-PAGE. The purified protein fractions were concentrated using $10 \mathrm{kDa}$ cut-off concentrator tubes to a certain volume before undergoing an overnight dialysis in phosphate buffer that contained $20 \mathrm{mM} \mathrm{NaCl}$. All the purified CBM 40 proteins were kept at $-80^{\circ} \mathrm{C}$ until further use.

\section{Effects of temperature and $p H$ on the stability of the purified CBM40}

The thermal stability of the recombinant CBM40 protein was monitored using a thermal shift assay CFX Connect ${ }^{\text {TM }}$ Real-Time PCR System (Biorad) through the midpoint of protein melting temperature $\left(\mathrm{T}_{\mathrm{m}}\right)$. About $2.5 \mathrm{mg} / \mathrm{ml}$ of the purified CBM40 enzyme was tested in different buffers (20 mM Tris $\mathrm{pH}$ 6.5, $20 \mathrm{mM}$ Tris $\mathrm{pH} 7.5$, $100 \mathrm{mM}$ potassium phosphate $\mathrm{pH} 6.5,100 \mathrm{mM}$ potassium phosphate $\mathrm{pH} 7.5,100 \mathrm{mM}$ sodium phosphate $\mathrm{pH} 6.5,100 \mathrm{mM}$ sodium phosphate $\mathrm{pH} 7.5,100 \mathrm{mM}$ sodium citrate $\mathrm{pH} 5.5$, and 100 $\mathrm{mM}$ sodium citrate $\mathrm{pH}$ 6.2) with $2.5 \mathrm{X}$ SYPRO Orange Dye. The samples were incubated as follows: $25^{\circ} \mathrm{C}$ for 30 seconds $(1$ cycle), followed by an increase of temperature to $100^{\circ} \mathrm{C}$ for 1 minute $(140$ cycles $)$ and a finishing cycle at $25^{\circ} \mathrm{C}$ for 1 minute. The fluorescence was read at a fixed absorbance of 492/610 $\mathrm{nm}$.

\section{Effects of metal ions and chemical reagents on the purified CBM40}

The effects of metal ions and chemical reagents are determined using a thermal shift assay CFX Connect ${ }^{\mathrm{TM}}$ Real-Time PCR System (Biorad). The reaction mixture consisted of the purified CBM40 $(2.5 \mathrm{mg} / \mathrm{ml})$ in $0.2 \mathrm{M}$ sodium citrate buffer, $\mathrm{pH}$ 5.5 containing $1 \mathrm{mM}$ of different metal ions $\mathrm{Na}^{2+}$, $\mathrm{Co}^{2+}, \mathrm{Zn}^{2+}, \mathrm{Ca}^{2+}, \mathrm{Mg}^{2+}, \mathrm{Fe}^{2+}, \mathrm{Mn}^{2+}, \mathrm{Cu}^{2+}$, and $\left.\mathrm{K}^{+}\right)$ and 2.5 X SYPRO Orange Dye. Meanwhile, the effect of surfactants (1\% Triton X-100, 1\% SDS), organic solvents (5\% DMSO, $1 \mathrm{M}$ urea), and metal chelator (1 $\mathrm{mM}$ EDTA) was also investigated on the purified CBM40. All tubes were incubated at $25^{\circ} \mathrm{C}$ for 30 seconds $(1$ cycle), followed by an increase of temperature from $25^{\circ} \mathrm{C}-100^{\circ} \mathrm{C}$ for 1 minute (140 cycles) and a finishing cycle at $25^{\circ} \mathrm{C}$ for 1 minute. The fluorescence emission was evaluated at a fixed wavelength of 492/610 $\mathrm{nm}$.

\section{RESULTS AND DISCUSSION}

\section{Molecular cloning of CBM40 gene}

The CBM40 gene of $585 \mathrm{bp}$, which was isolated from Vibrio cholerae Non-O1 sialidase was amplified and cloned in $\mathrm{pET}-22 \mathrm{~b}(+)$ vector and transformed in E. coli BL21(DE3) strain (Figure 2). The complete ORF sequence consists of 133 adenine (A), 68 thymine (T), 182 guanine $(G)$, and 202 cytosine (C) (Figure 3). Based on the analysis by Compute $\mathrm{pI} / \mathrm{Mw}$, the protein isoelectric point (pI) is 4.77 and its molecular weight is $21,074.32$ Da. Deduced amino acid sequence analysis showed $98.86 \%$ similarity to Vibrio cholerae Neuraminidase with Accession No. APF83226 and 2W68_A (Figure 4). The gene was cloned into pET-22b (+) vector and cultivated in E. coli BL21 (DE3) host. The pET-22b(+) expression vector encoded a pelB secretion signal peptide under strong bacteriophage T7 promoter (Sockolosky \& Szoka, 2013; Kashani et al., 2015). The presence of pelB signal peptide would direct the expression of CBM40 gene in the periplasmic space where 
the condition would improve protein folding (Yoon et al., 2010; Malik, 2016).

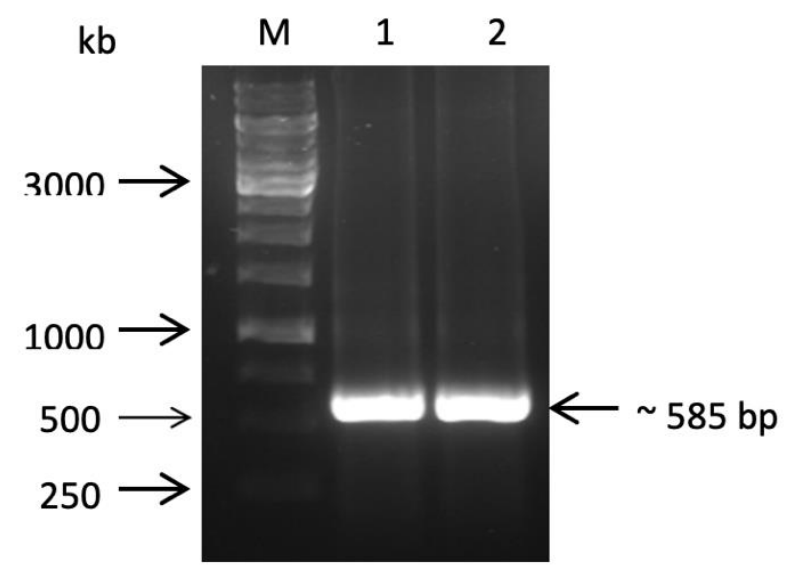

Figure 2. PCR amplification of CBM40 gene of Vibrio cholerae Non-01 sialidase.

\section{Overexpression and purification of CBM40 protein}

Expression of the CBM40 protein was carried out in E. coli BL21 (DE3) harbouring the pET-22b(+) vector. This vector carried the N-terminal pelB secretion signal peptide, which targeted the unfolded state of the translated protein to the $E$. coli periplasm via the Sec-dependent transport pathway (Yoon et al., 2010). This pelB signal peptide is cleaved upon secretion to the periplasm and the presence of chaperones molecule and disulphide bond isomerases, which are located in the E. coli periplasm space help to properly fold the protein, and thus making it an ideal compartment for various therapeutic protein expressions (Sockolosky \& Szoka, 2013). In order to express CBM40 protein in soluble form, it was important to go through an additional stage of heat-shock treatment at $42^{\circ} \mathrm{C}$ for 30 minutes before inducing with $1 \mathrm{mM}$ IPTG. After carrying out this additional step, the protein solubility has significantly improved and at the same time, the induction levels were not affected. Crucial stage like heat shock at $42^{\circ} \mathrm{C}$ could lead to expression of E. coli heat-shock proteins, which act as molecular chaperones and assist protein folding and disassemble protein aggregates. The existence of bacteria chaperones has been widely discovered in E. coli insoluble fraction due to the formation of fusion protein aggregation (Carrió \& Villaverde, 2005; Guenther et al., 2012). Intracellular chaperones known as heat shock proteins act to assist protein-protein interactions, such as folding, proper protein conformation, and also prevent unwanted protein aggregation. These heat shock proteins help transport proteins across cell membranes and stabilize partially unfolded proteins (Bakthisaran et al., 2015). In addition, deficiency of eukaryotic chaperones molecule and post-translational modification mechanism also assist in the inclusion bodies formation in bacteria (Carrió et al., 2000; Walter \& Buchner, 2002).

In order to investigate the effect of different post-induction time on the yield of recombinant CBM40, five incubation times $(4,8,12,16$, and 20 hours) were evaluated. According to our results, the highest protein expression was observed at 20 hours after the post-induction time (Figure 5). Despite using lower post-induction temperature of $18^{\circ} \mathrm{C}$ to slow down protein folding and fusion protein oligomerization, some of the proteins were still expressed as insoluble form in the pellet. According to Hoell et al. (2005), incompatible growth temperature can cause protein misfolding, which eventually promotes inclusion bodies formation. Previous studies have suggested to use low expression temperature to promote the formation of correctly folded protein and soft inclusion bodies where non-denaturing solvents can be used as solubilizing agents (Jevševar et al., 2005; Peternel et al., 2008; Alias et al., 2009). Besides that, protein expression at a high translational rate often resulted from unsuitable post-induction temperature, higher concentration of inducer, and strong promoter system, which also lead to protein aggregations and inclusion bodies formation (Costa et al., 2014). Inclusion bodies are highly dynamic in nature but they can be reversibly converted to their native form by proper strategies during protein recovery (Singh $e t$ al., 2015). 
1 GGC GCC ATG GCC CTG TTC GAC TAC AAC GCC ACC GGC GAC ACC GAG TTC GAC AGC CCC GCC 60

$\begin{array}{llllllllllllllllllllll}1 & G & A & M & A & \text { L } & \text { F } & \text { D } & \text { Y } & \text { N } & \text { A } & \text { T } & \text { G } & \text { D } & \text { T } & \text { E } & \text { F } & \text { D } & \text { S } & \text { P } & \text { A } & 20\end{array}$

61 AAg CAG GGC TGG ATG CAG GAC AAC ACC AAC AAC GGC AGC GGC GTT TTA ACC AAT GCA GAT 120

$\begin{array}{lllllllllllllllllllllll}21 & \mathrm{~K} & \mathrm{Q} & \mathrm{G} & \mathrm{W} & \mathrm{M} & \mathrm{Q} & \mathrm{D} & \mathrm{N} & \mathrm{T} & \mathrm{N} & \mathrm{N} & \mathrm{G} & \mathrm{S} & \mathrm{G} & \mathrm{V} & \mathrm{L} & \mathrm{T} & \mathrm{N} & \mathrm{A} & \mathrm{D} & 40\end{array}$

121 GGA ATG CCC GCT TGG TTG GTG CAA GGT ATT GGA GGg AGA GCT CAA TGg ACA TAT TCT CTC 180

$\begin{array}{llllllllllllllllllllll}41 & \mathrm{G} & \mathrm{M} & \mathrm{P} & \mathrm{A} & \mathrm{W} & \mathrm{L} & \mathrm{V} & \mathrm{Q} & \mathrm{G} & \mathrm{I} & \mathrm{G} & \mathrm{G} & \mathrm{R} & \mathrm{A} & \mathrm{Q} & \mathrm{W} & \mathrm{T} & \mathrm{Y} & \mathrm{S} & \mathrm{L} & 60\end{array}$

181 TCT ACT AAT CAA CAT GCC CAA GCA TCA AGT TTC GGT TGG CGA ATG ACG ACA GAA ATG AAA 240

$\begin{array}{llllllllllllllllllllll}61 & \mathrm{~S} & \mathrm{~T} & \mathrm{~N} & \mathrm{Q} & \mathrm{H} & \mathrm{A} & \mathrm{Q} & \mathrm{A} & \mathrm{S} & \mathrm{S} & \mathrm{F} & \mathrm{G} & \mathrm{W} & \mathrm{R} & \mathrm{M} & \mathrm{T} & \mathrm{T} & \mathrm{E} & \mathrm{M} & \mathrm{K} & 80\end{array}$

241 GTg CTC Agt Ggt GgA ATg ATC ACA AAC TAC TAC GCC AAC GGC ACt CAg CGT GTC TTA CCC 300

$\begin{array}{lllllllllllllllllllllll}81 & \text { V } & \text { L } & \text { S } & \text { G } & \text { G } & \text { M } & \text { I } & \text { T } & \text { N } & \text { Y } & \text { Y } & \text { A } & \text { N } & \text { G } & \text { T } & \text { Q } & \text { R } & \text { V } & \text { L } & \text { P } & 100\end{array}$

301 ATC ATt TCA TTA GAT AGC Agt GGT AAC TTA GTT GTT GAg TTt GAA GGg CAA ACT GGA CGC 360

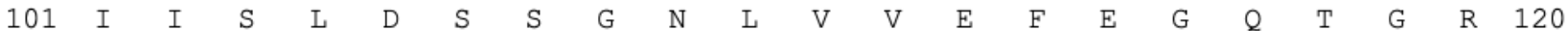

361 ACC GTT TTG GCA ACC GGC ACA GCA GCA ACG GAA TAT CAT AAA TTT GAA TTG GTA TTC CTT 420

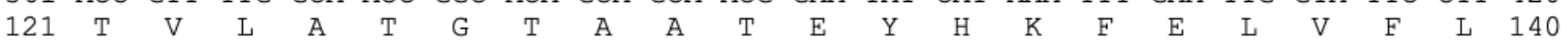

421 CCT GGA AGT AAC CCA TCC GCT AGC TTT TAC TTC GAT GGC AAA CTC ATT CGT GAC AAC ATC 480

$\begin{array}{llllllllllllllllllllllll}141 & \mathrm{P} & \mathrm{G} & \mathrm{S} & \mathrm{N} & \mathrm{P} & \mathrm{S} & \mathrm{A} & \mathrm{S} & \mathrm{F} & \mathrm{Y} & \mathrm{F} & \mathrm{D} & \mathrm{G} & \mathrm{K} & \mathrm{L} & \mathrm{I} & \mathrm{R} & \mathrm{D} & \mathrm{N} & \mathrm{I} & 160\end{array}$

481 CAg CCG ACT GCA TCA AAA CAA AAT ATG ATC GTA TGG GGG AAT GGC TCA TCA AAT ACG GAT 540

$\begin{array}{llllllllllllllllllllllll}161 & Q & \mathrm{P} & \mathrm{T} & \mathrm{A} & \mathrm{S} & \mathrm{K} & \mathrm{Q} & \mathrm{N} & \mathrm{M} & \mathrm{I} & \mathrm{V} & \mathrm{W} & \mathrm{G} & \mathrm{N} & \mathrm{G} & \mathrm{S} & \mathrm{S} & \mathrm{N} & \mathrm{T} & \mathrm{D} & 180\end{array}$

541 GGT GTC GCC GCT TAT CGT GAT ATT AAG TTT GAA ATT CAA GGC GAC 585

$\begin{array}{llllllllllllllllll}181 & G & \text { V } & \text { A } & \text { A } & \text { Y } & \text { R } & \text { D } & \text { I } & \text { K } & \text { F } & \text { E } & \text { I } & \text { Q } & \text { G } & \text { D } & 195\end{array}$

Figure 3. The gene sequences of CBM40 of Vibrio cholerae Non-O1 sialidase. The translated amino acid sequence is shown in one-letter codes below the nucleotide sequence.

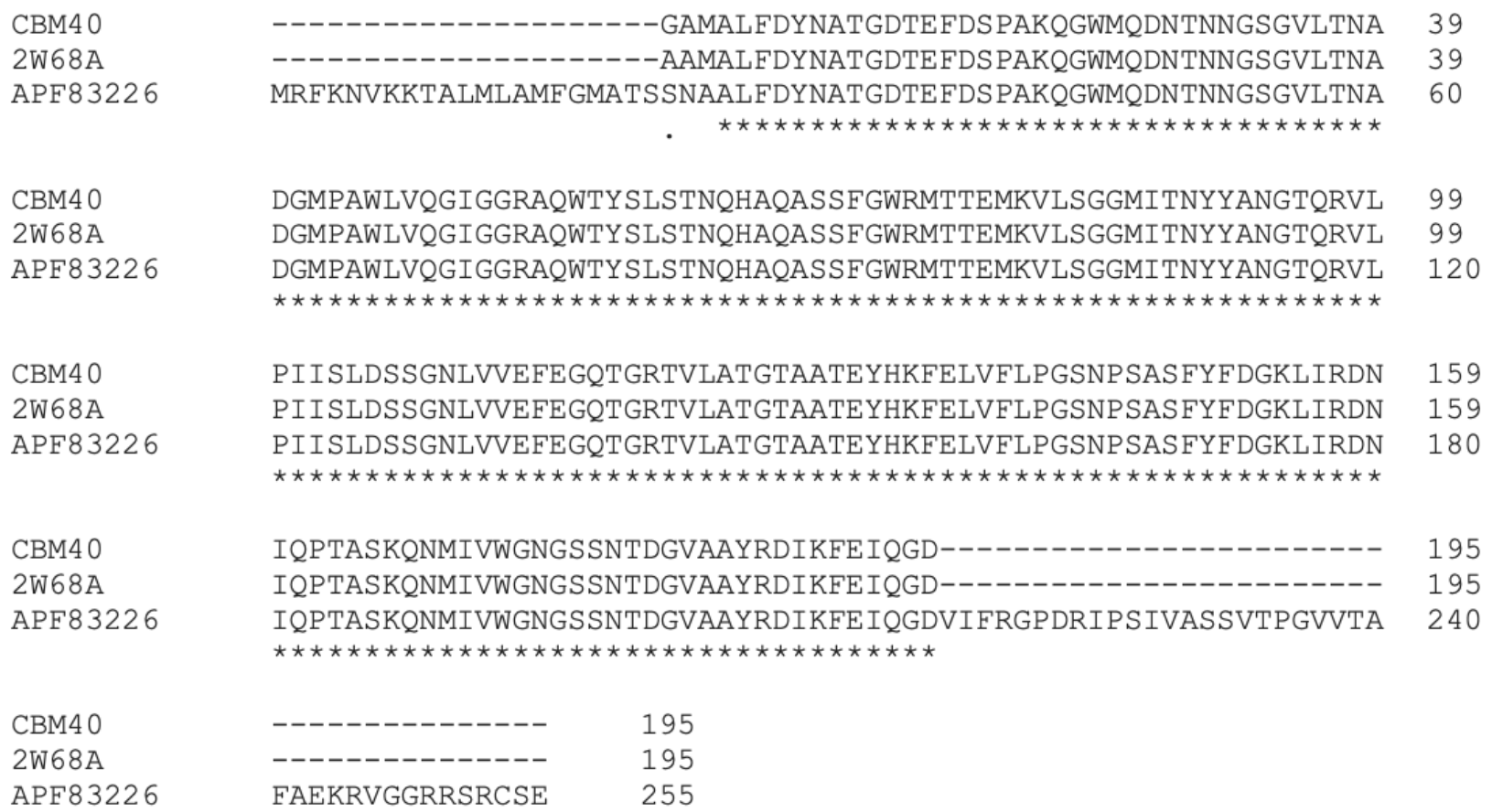

Figure 4. The alignment of the amino acid sequence of the recombinant CBM40 gene of the Vibrio cholerae Neuraminidases (Accession No. APF83226 and 2W68_A). The alignment was performed using the Clustal Omega program. 


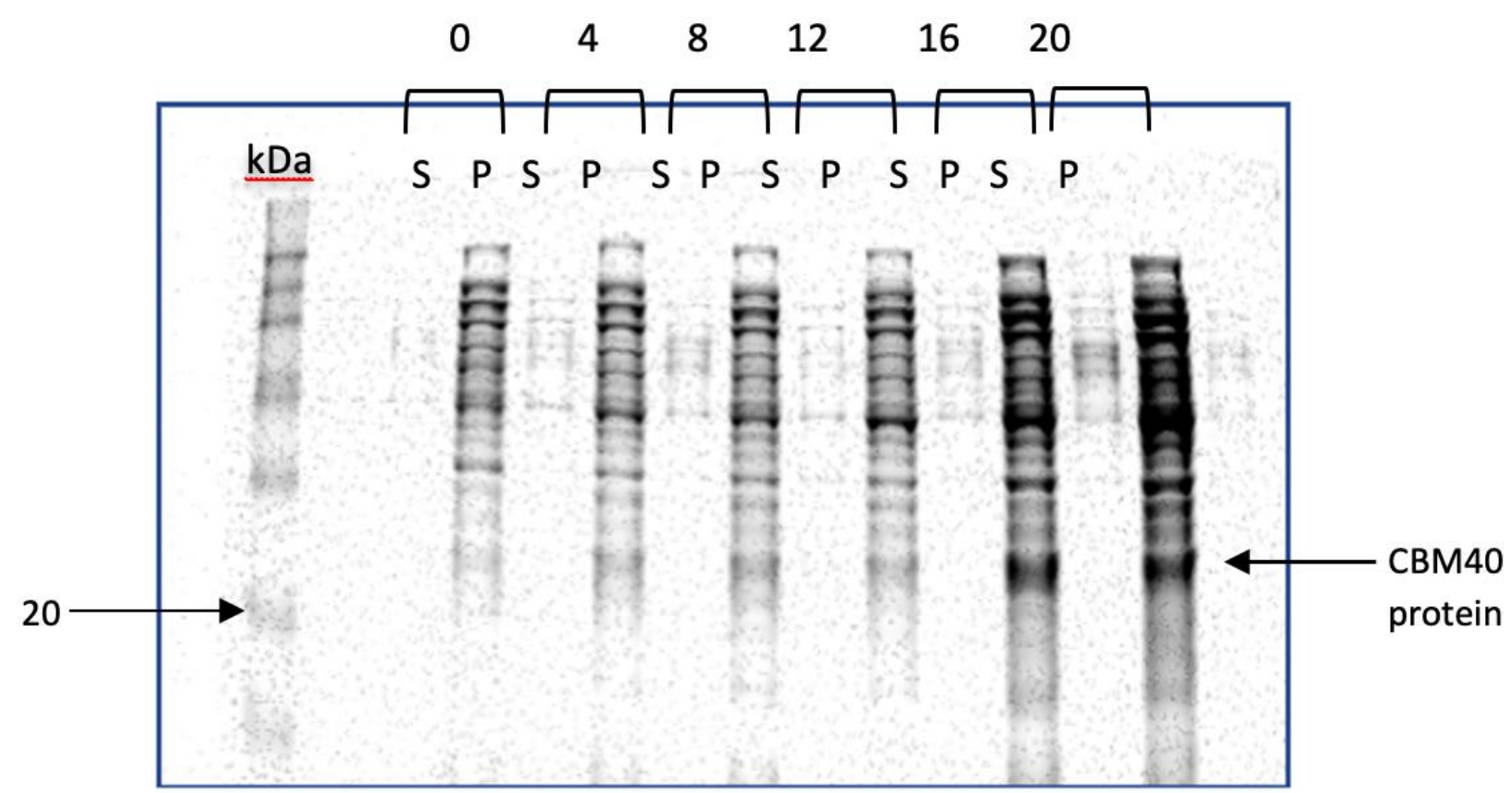

Figure 5. Expression of the recombinant CBM40 protein at different time interval from 4 hours until 20 hours after post induction time. All samples were sonicated and separated by centrifugation. S: Supernatant; P: Pellet.

In order to recover inactive CBM40 protein from the pellet, four main strategies were carried out as stated by Singhvi et al. (2020), which were inclusion bodies isolation, homogeneous inclusion bodies solubilization, refolding of the solubilized proteins, and refolded proteins purification through chromatographic approaches (Singhvi et al., 2020). In order to solubilize the pellet, sonication was performed on ice in an anionic denaturing buffer containing 1\% w/v SDS and 0.1\% sarkosyl. Shlager et al. (2012) stated that adding both $0.1 \%$ sarkosyl and 1\% SDS in the lysis buffer helped to break the protein solubility barrier. Another study by Burgess (2009) mentioned that adding as low as $0.1 \%$ to $2 \%$ of sarkosyl in the lysis buffer led to the improvement of protein solubility from inclusion bodies. Previous research by Massiah et al. (2016) stated that an addition of $10 \%$ sarkosyl in the buffer helped recover more than $95 \%$ of active protein from the inclusion bodies, thus enhanced protein solubility and efficiently helped in the cell lysis. Besides that, as reported by Jevševar et al. (2005), in order to solubilise inclusion bodies, less concentrated organic solvents such as 5\% npropanol, 5\% DMSO, $2 \mathrm{M}$ urea, and $0.1 \%$ and $0.2 \% \mathrm{~N}$-lauryl sarcosine (detergent) were used as mild solubilization agents (Jevševar et al., 2005; Upadhyay et al., 2014). These mild solubilization techniques have been proven to enhance bioactive protein recovery from inclusion bodies (Burgess, 1996; Kudou et al., 2011). Furthermore, as reported by Singh et al. (2015), for protein containing multiple cysteine residues, reagents such as $\beta$-mercaptoethanol or dithiothreitol (DTT) are normally added during the solubilization stage to decrease the misformation of disulfide bond.

The lysates were then cooled down to precipitate free SDS, which also contained trace amounts of protein. Centrifugation helped to separate the precipitated SDS from host proteins and overexpressed target protein. Usually, the isolated inclusion bodies contain certain impurities, such as proteins from the host, membrane fragments, and RNA, hence, further purification steps need to be carried out. During refolding of the solubilized proteins, removal of solubilization agents with optimal refolding buffer is very important. Many chromatographic techniques have been widely used for protein refolding, which included size exclusion, ion exchange, and affinity chromatography. Choosing the correct and suitable chromatography methods is very crucial in order to optimize and recover a large quantity of bioactive protein from the inclusion bodies. In this study, affinity column chromatography was performed using HisTrap 
FF column. For protein purification, two-step strategy of the affinity chromatography was carried out with the final concentration of $50 \mathrm{mM}$ imidazole. Improved protein purity was observed after elution with gradient imidazole concentrations $(10-50 \mathrm{mM})$. As seen in Figure 6, most of the high molecular weight protein contaminants associated with the protein of interest were successfully removed. The purified CBM40 protein displayed a protein molecular mass of $21 \mathrm{kDa}$ on SDS PAGE (Figure 6).

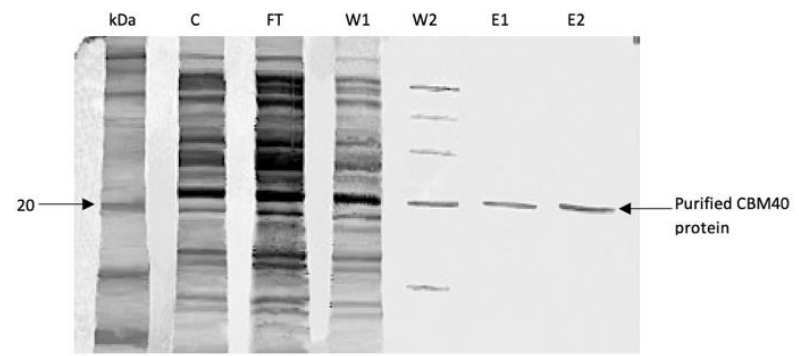

Figure 6. Purified CBM40 protein showed an approximate size of $21 \mathrm{kDa}$ after purification stages. M: Protein marker; C: Crude enzyme; FT: Flow through; W1-W2: Wash stages; E1-E2: Elution stages.

\section{Temperature and $p H$ stability studies of purified CBM40}

Protein characterization is one of the important stages to be analysed especially for a newly developed engineered protein. Protein characterization profile is related to protein separation, purity, and also its biological, chemical, and physical properties. So, when it comes to developing a strategy for protein characterizations, a few factors need to be considered, which include protein purity and its stability. There are several options of biophysical techniques available to measure protein interactions, such as direct fluorescence-based method known as thermal shift assay. In this assay, protein thermal stability can be calculated through the temperature midpoint or melting point $\left(\mathrm{T}_{\mathrm{m}}\right)$ of the protein samples' curve. Melting temperature $\left(T_{\mathrm{m}}\right)$ is defined as the temperature where $50 \%$ of the protein molecules are unfolded. According to Niesen et al. (2007), protein structure is likely denatured at certain temperatures and throughout this process, the protein midpoint can be measured. Protein with higher $\mathrm{T}_{\mathrm{m}}$ value will have greater thermal resistance since a higher temperature is needed to unfold the protein structure.

The importance of buffers as part of the integral component of protein formulations helped to stabilize protein by specific mechanisms. The addition of buffers not only helped to regulate $\mathrm{pH}$ shifts but also managed to increase protein conformation stability either by ligand binding or through excluded solute mechanism (Zbacnik et al., 2017). From Figure 7, the highest stability of the protein was obtained in $100 \mathrm{mM}$ citrate buffer at $\mathrm{pH} 5.5$, with melting temperature of $40^{\circ} \mathrm{C}$. The protein exhibited stability between $\mathrm{pH}$ 5.5-6.2 and was able to retain its activity from $27-56^{\circ} \mathrm{C}$. In contrast to CBM32 isolated from Thalassomonas sp. LD5, the protein has optimal enzymatic activity at $30^{\circ} \mathrm{C}$ and $\mathrm{pH}$ at 7.6, as reported by Zhang et al. (2019). Therefore, these data suggested that CBM40 had a slightly better thermal stability with $10^{\circ} \mathrm{C}$ higher temperature as compared to CBM32. In addition, for optimal $\mathrm{pH}$ condition, the results showed that both CBMs had a significant effect on the optimal $\mathrm{pH}$ of the enzyme where CBM40 exhibited better protein stability in highly acidic environment in contrast to CBM32, which showed stability in alkaline environment. Based on previous research by Ali et al. (2005) on family 22 CBM from thermostable strain of Clostridium thermocellum Xyn10C, the contiguous presence of CBM domain to the catalytic module increased the enzyme optimal temperature to $80^{\circ} \mathrm{C}$ from $60^{\circ} \mathrm{C}$ when $\mathrm{CBM}$ domain was attached. Meanwhile, $\mathrm{pH}$ of the recombinant $\mathrm{CBM}$ (rCBM-CM) protein was also found to be more stable in acidic $\mathrm{pH}$ range (Ali et al., 2005). In addition, according to Zhou and Pang (2018), protein stability will be affected by $\mathrm{pH}$ of buffers and the electrostatic interactions between charged amino acids present on the protein. Through thermal shift assay, the consequent changing of protein melting temperature $\left(\mathrm{T}_{\mathrm{m}}\right)$ in a solution can be applied to measure protein stability at different relative $\mathrm{pHs}$. According to a study by De Lencastre et al. (2011), the addition of phosphate and citrate in Green Fluorescent Protein (GFP) expression showed that both citrate and phosphate aided to protect GFP protein from inactivation at elevated temperatures from $70-90^{\circ} \mathrm{C}$ by promoting protein conformation stability. These salts bind to the native protein state and stabilize it via their 
anionic multivalent interactions. Another study by Byrt et al. (2012) on the hydrolytic activity of cellulase enzyme found that the existence of CBM next to the enzyme molecule did not reduce the rate of enzyme hydrolysis. In addition, it increased the protein stability towards $\mathrm{pH}$ changes, which were between $\mathrm{pH} 4.0$ and 5.5. This was in agreement with a study by Liu and Ding (2016), which also reported that thermostability of cellulases and hemicellulases enzyme against lignocellulosic substrate improved when CBM42 domain was fused to the main enzyme. This approach thus significantly enhanced the enzyme catalytic activity and thermostability towards 4methylumbelliferyl acetate substrate. A study by Koseki et al. (2010) on chimeric enzyme of Aspergillus awamori feruloyl esterase and family 42 CBM managed to retain the enzyme activity up to $40 \%$ after incubation at $55^{\circ} \mathrm{C}$ for 30 minutes as opposed to the enzyme without CBM domain, which had lost activity at the same temperature tested. Therefore, this showed the role of CBM in maintaining the thermal stability of protein.

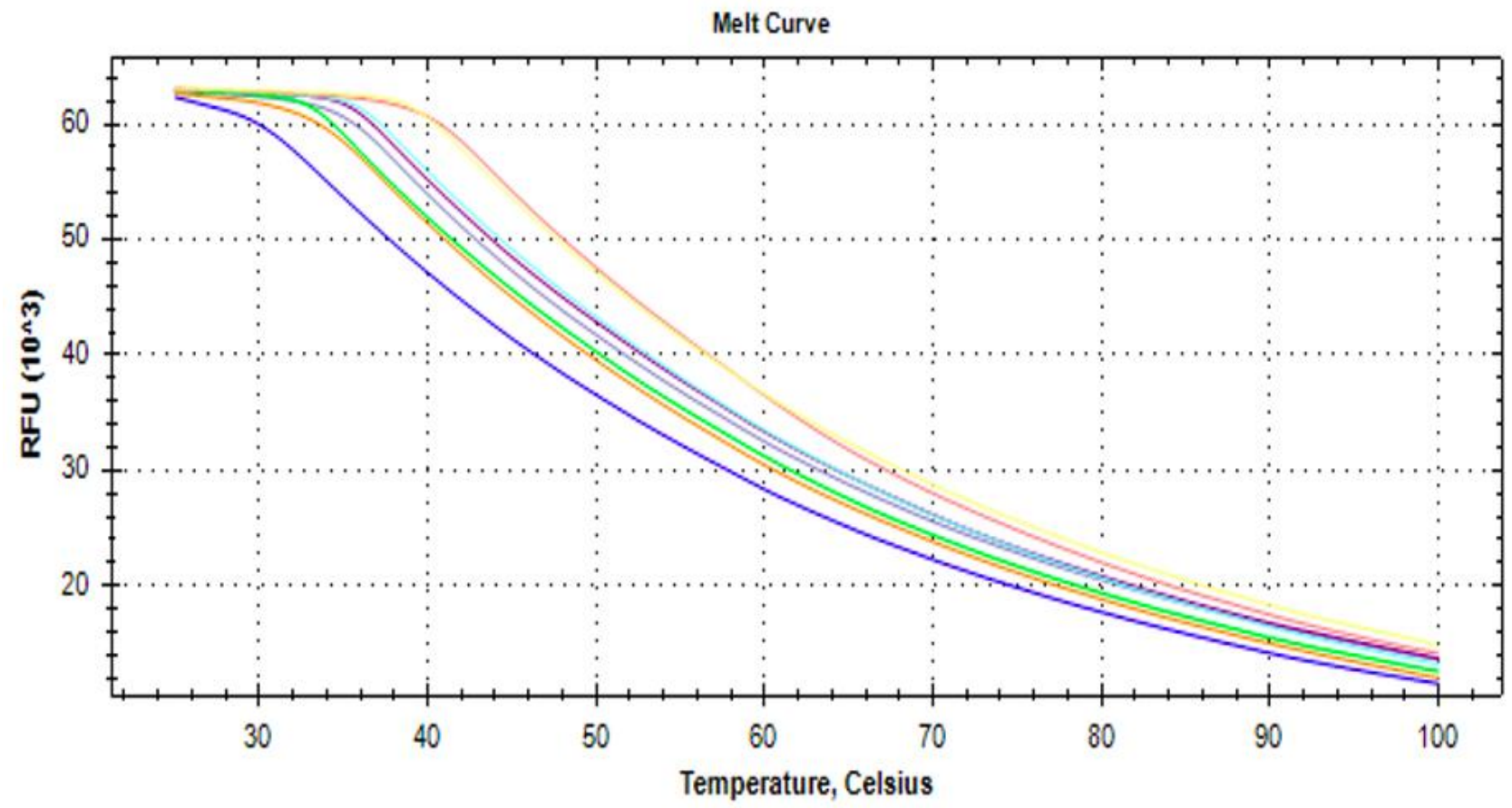

Figure 7. Protein melting curve analysis for the CBM40 in different buffers. $(-) 100 \mathrm{mM}$ sodium citrate $\mathrm{pH} 5.5,(\square) 100 \mathrm{mM}$ sodium citrate $\mathrm{pH} 6.2,(-) 100 \mathrm{mM}$ potassium phosphate $\mathrm{pH} 6.5,(-) 100 \mathrm{mM}$ potassium phosphate $\mathrm{pH} 7.5,(-) 100 \mathrm{mM}$ sodium phosphate $\mathrm{pH} 6.5,(-) 100 \mathrm{mM}$ sodium phosphate $\mathrm{pH} 7.5,(-) 20 \mathrm{mM}$ Tris $\mathrm{pH} 6.5$ and $(-) 20 \mathrm{mM}$ Tris $\mathrm{pH} 7.5$.

\section{Effect of metal ions and reagents on stability of CBM40}

One of the approaches to stabilize protein structure and mechanism is identifying the interaction of metal ions with specific amino acid on a protein (Kardinahl et al., 2000; Villalonga et al., 2004). The effect of metal ions $\left(\mathrm{Na}^{2+}, \mathrm{Ca}^{2}+\right.$, $\mathrm{Co}^{2+}, \mathrm{Cu}^{2+}, \mathrm{Fe}^{2+}, \mathrm{Mn}^{2+}, \mathrm{Mg}^{2+}, \mathrm{Zn}^{2+}$, and $\mathrm{K}^{+}$) on the stability of CBM40 domain was determined by the thermal shift assay approach (Figure 8). From the temperature curve analysis, $\mathrm{Mn}^{2+}$ and $\mathrm{Mg}^{2+}$ ions managed to increase protein melting temperature to $56^{\circ} \mathrm{C}$ as compared to other metal ions including the control (sample without addition of metal ion). Meanwhile, $\mathrm{K}^{+}$showed the lowest $\mathrm{T}_{\mathrm{m}}$, which was around $40^{\circ} \mathrm{C}$ (Figure 8). A previous study on human lymphotactin revealed that protein function and its structure could be coordinated by ionic interactions between metal ion and salts (Formaneck et al., 2006). The roles of electrostatic interactions in protein folding involved in protein-metal complexes show that metals are utilized by proteins in cells on a molecular level, which affects thermodynamic and kinetic properties of proteins. Effect of metal ions and reagents on protein folding and unfolding depends on types and concentration of metal ions, ionic strengths, and also protein-charged residues. 
These factors affect both native protein and denatured states of the protein (Palm-Espling et al., 2012). A study by Zhang et al. (2020) on CBM32 and CBM9 from a marine bacterium, Thalassomonas sp. LD5 revealed that combination of both domains, i.e. CBM9 and CBM32 to the main protein managed to maintain $5 \%$ of its activity up to $80^{\circ} \mathrm{C}$, which enhanced thermostability. The addition of $\mathrm{Ca}^{2+}$ into the protein reaction led to $14 \%$ increase in the protein activity compared to the reaction without metal ion. These results proved that CBM9 and CBM32 improved the catalytic module activity against metal ion. Nevertheless, when comparing their melting temperature without the addition of metal ion, CBM40 showed a relatively higher melting temperature of $40^{\circ} \mathrm{C}$ as compared to the chimeric protein (CBM9-CBM32), which was at $30^{\circ} \mathrm{C}$.

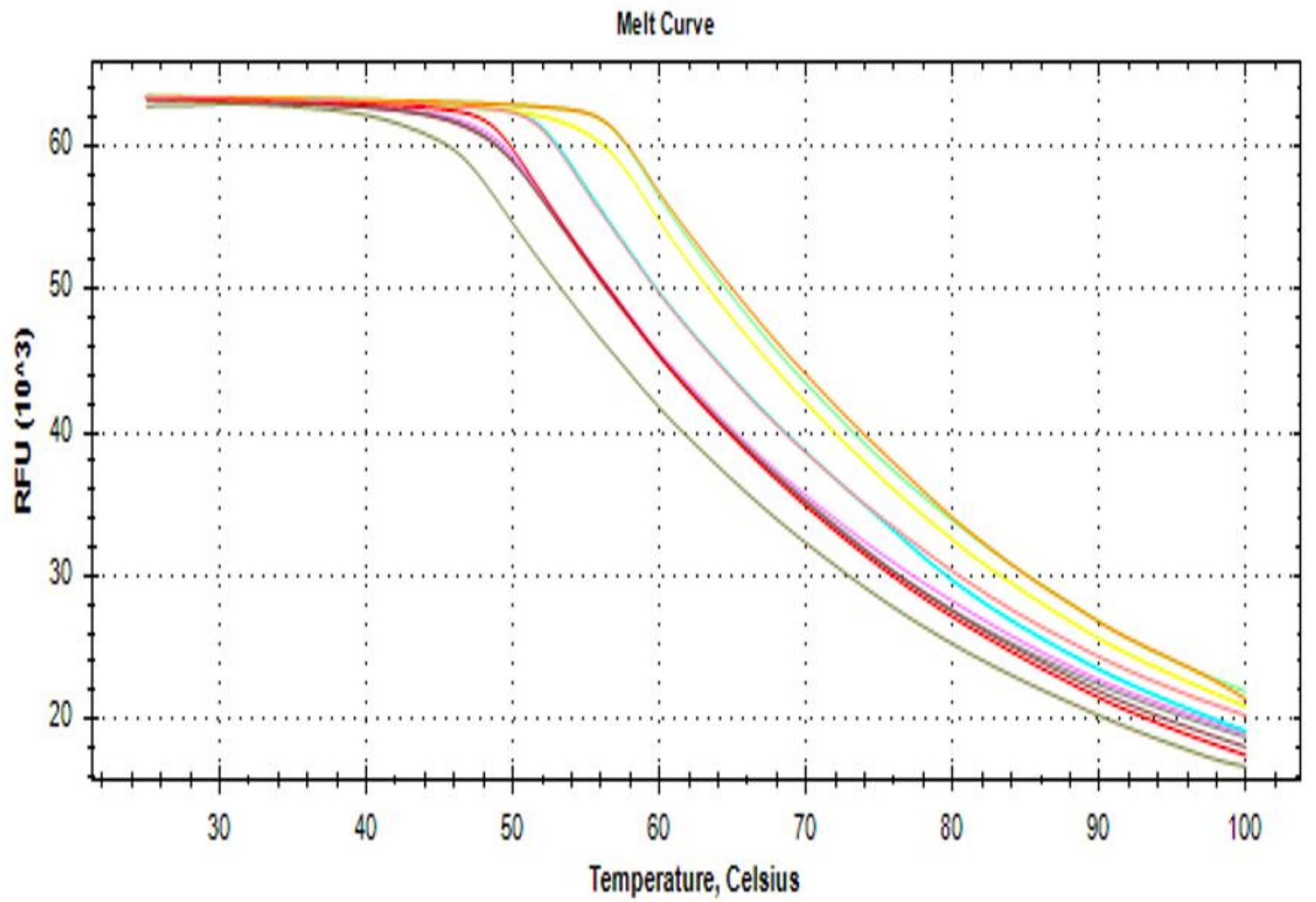

Figure 8. Effect of metal ions on protein melting temperature analysis. $(\square)$ Control $,(-) \mathrm{Co}^{2+},(-)$ $\mathrm{Mn}^{2+},(-) \mathrm{K}^{+},(-) \mathrm{Cu}^{2+},(-) \mathrm{Zn}^{2+},(-) \mathrm{Mg}^{2+},(-) \mathrm{Na}^{2+},(-) \mathrm{Fe}^{2+}$ and $(\square) \mathrm{Ca}^{2+}$.

Due to the protein stabilization complex, protein stability can be deliberated through the increase in melting temperature. The presence and absence of ligands can lead to differences in melting temperature, which correlate to substrate and protein molecule binding affinity. Various research found that greater than three-tenths of many folded proteins have metal ions bound to specific sites on the proteins in order to obtain the desired function (Lin et al., 2006; Palm-Espling et al., 2012). Metal ions have been proven to play significant roles in protein structural stability (i.e. zinc in zinc-finger domains) and enzyme metabolisms by the mechanism of metal-bound proteins, which folds in cellular environments where their related metal ions are present free in solution or bound to delivery proteins (i.e. zinc in carbonic anhydrase) (Palm-Espling et al., 2012). Based on a study carried out by Sissi and Palumbo (2009) on the effects of divalent metal ion $\left(\mathrm{Mg}^{2+}\right)$, this cofactor helped in improving topoisomerases DNA cleavage through supporting the catalytic events. On the contrary, metal ions destabilizing effect of $\mathrm{Na}^{+}, \mathrm{Ca}^{2+}$, and $\mathrm{Mg}^{2+}$ on recombinant pyrolysin protein was been observed due to the disruption of protein surface electrostatic 
interactions. Notably, the protein's melting curve was shifted to a lower temperature, displaying destabilizing effects on the tested divalent cations. This destabilizing effect may also be compensated by other biotic and abiotic factors (Zeng et al., 2014). Another study by Villalonga et al. (2004) on trypsin also found that $\mathrm{Mg}^{2+}, \mathrm{Zn}^{2+}$, and $\mathrm{Mn}^{2+}$ metal ions helped to increase trypsin thermal stability up to four-fold after the addition of the respective metal ions. Therefore, correlated from that study, the addition of $\mathrm{Mn}^{2+}$ and $\mathrm{Mg}^{2+}$ ions also showed a significant impact on CBM40 protein thermal stability (up to $56^{\circ} \mathrm{C}$ ) as compared to other metal ions tested.

In addition, stability effect of reagents on the purified CBM40 protein was tested using five different reagents, namely $1 \mathrm{M}$ urea, $1 \mathrm{mM}$ EDTA, 1\% SDS, 5\% DMSO, and 1\% Triton X100 in $100 \mathrm{mM}$ sodium citrate buffer $\mathrm{pH}$ 5.5. From the observation, three reagents $(1 \%$ Triton
$\mathrm{X}-100,1 \%$ SDS, and $1 \mathrm{M}$ urea) managed to slightly increase the melting temperature of the recombinant CBM40 protein (Figure 9). The highest melting temperature was found after the addition of $1 \% \mathrm{SDS}$, which was at $55^{\circ} \mathrm{C}$, followed by $1 \mathrm{M}$ urea and $1 \%$ Triton-X at $54^{\circ} \mathrm{C}$ and $52^{\circ} \mathrm{C}$, respectively. From this study, the addition of polar aprotic solvent-like DMSO and the chelating agent EDTA showed a lower melting temperature which was at $38^{\circ} \mathrm{C}$ and $46^{\circ} \mathrm{C}$, respectively as compared to the control when reacted with the CBM40 protein. A previous study by $\mathrm{Lu}$ et al. (2014) reported that recombinant gene CBM1 and Aspergillus nidulans endo-3-1,4-mannanase (Man5XZ3) managed to retain higher enzymatic activity (more than $80 \%$ ) in the presence of chaotropic agent (4 M urea), $60 \%$ acetone, and two surfactants $(1 \%$ SDS and $1 \%$ Triton $\mathrm{X}-100)$ as compared to the protein alone without the CBM1 domain.

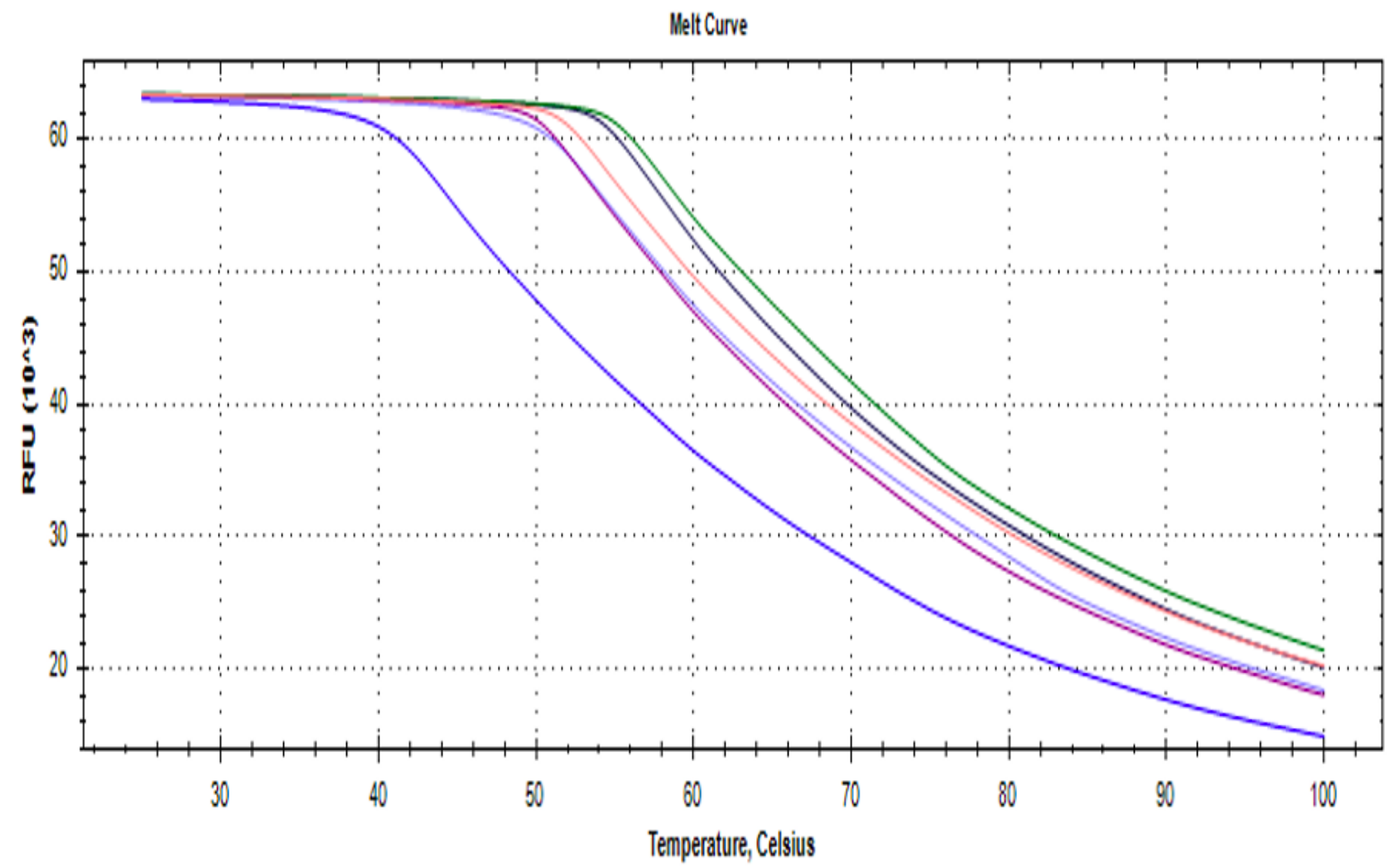

Figure 9. Effect of different chemical reagents on CBM40 protein stability. $(\square)$ Control, $(\square) 1 \%$ SDS, (-) 5\% DMSO, (-) 1\% Triton X-100, (-) 1 mM EDTA, (-) 1 M urea.

Based on a previous study by Pereira et al. (2017), the addition of anionic detergent, such as sodium dodecyl sulphate (SDS) at low concentrations of 1-2 $\mathrm{mM}$ would enhance the enzyme activity, while could cause inhibitory effect at $20 \mathrm{mM}$ concentration. Higher concentration of SDS would interfere in the hydrophobic regions of a protein, thus modifying protein threedimensional structure and causing enzyme denaturation (Bhuyan, 2010). A study conducted 
by Szymczyk et al. (2018) on different non-ionic detergents (Tween-20, Tween-40, Tween-60, Tween-80, Tween-100, Triton X-100, and polyethylene glycol (PEG)) had proven to reduce the fluidic systems' surface tension, which led to changes in liquid properties. Even though Triton $\mathrm{X}-100$ is a non-ionic mild detergent that usually leads to slow cell lysis, this reagent has the tendency to denature proteins and break up protein complexes (Islam et al., 2017). Based on this study, the CBM40 melting temperature was distinguished by only $1{ }^{\circ} \mathrm{C}$ when SDS and urea were added to the protein mixture. Some of the advantages of using SDS in protein purification over urea are that SDS can be applied at comparably low concentrations and does not tend to crystallize in valves and pumps of chromatography devices, such as FPLC (Schlager et al., 2012).

\section{CONCLUSION}

In this study, the recombinant CBM40 was successfully expressed in Escherichia coli BL21(DE3) strain despite having inclusion bodies formation. Our study indicated that the yield of recombinant CBM40 was markedly increased when produced under optimized protocol. The purified CBM40 showed an increase in thermal stability to withstand acidic environment and was able to retain its activity at a short period of time by increasing the temperature up to $50^{\circ} \mathrm{C}$. The addition of metal ions managed to increase protein melting temperature, meanwhile, the addition of lower concentrations of ionic, nonionic, and chaotropic detergents showed a significant increase in protein stability. This discovery provides new insights on the development of stable recombinant family 40 $\mathrm{CBM}$, which can be further developed as a potential biologic molecule for diagnostic uses in the biotechnology and biomedical fields.

\section{ACKNOWLEDGEMENTS}

The authors wish to thank Assoc. Prof. Dr. John Tang Yew Huat from Faculty of Bioresources and
Food Industry, Universiti Sultan Zainal Abidin, Besut Campus, Terengganu, Malaysia for supplying Vibrio cholerae Non-O1 strain used in this study. Part of this work was supported by Fundamental Research Grant Scheme (FRGS)FRGS/1/2018/STG05/UNISZA/02/1 from Ministry of Higher Education Malaysia.

\section{REFERENCES}

Ali, E., Zhao, G., Sakka, M., Kimura, T., Ohmiya, K., \& Sakka, K. 2005. Functions of family-22 carbohydrate-binding module in Clostridium thermocellum Xyn10C. Bioscience, Biotechnology and Biochemistry 69(1): 160-165.

Alias, N., Mahadi, N. M., Murad, A. M. A., Bakar., F. D. A., Mahmood, N. A. N., \& Illias, R. M. 2009. Expression and characterization of Trichoderma virens UKM-1 endochitinase in Escherichia coli. World Journal of Microbiology and Biotechnology, 25: 561-572.

Alias, N., \& Mamat, S. 2018. Isolation and molecular cloning of carbohydrate-binding module (CBM40) from Vibrio cholerae Non-O1 Neuraminidase. Journal of Agrobiotechnolog 9(2): 108118.

Bakthisaran, R., Tangirala, R., \& Rao, C. M. 2015. Small heat shock proteins: Role in cellular functions and pathology. Biochimica et Biophysica Acta - Proteins and Proteomics 1854(4): 291-319.

Bhuyan, A. K. 2010. On the mechanism of SDS-induced protein denaturation. Biopolymers 93(2): 186-199.

Burgess, R. R. 1996. Purification of overproduced Eschericbia coli RNA polymerase $\sigma$ factors by solubilizing inclusion bodies and refolding from Sarkosyl. Methods in Ensymology 273: 145-149.

Burgess, R. R. 2009. Chapter 17-Refolding Solubilized Inclusion Body Proteins. Methods in Ensymology 463: 259-282.

Byrt, C. S., Cahyanegara, R., \& Grof, C. P. L. 2012. Plant carbohydrate binding module enhances activity of hybrid microbial cellulase enzyme. Frontiers in Plant Science 3(254): $1-8$.

Carrió, M. M., Cubarsi, R., \& Villaverde, A. 2000. Fine architecture of bacterial inclusion bodies. FEBS Letters 471(1): 7-11.

Carrió, M. M., \& Villaverde, A. 2005. Localization of chaperones DnaK and GroEL in bacterial inclusion bodies. Journal of Bacteriology 187(10): 3599-3601.

Connaris, H., Govorkova, E. A., Ligertwood, Y., Dutia, B. M., Yang, L., Tauber, S., Taylor, M. A., Alias, N., Hagan, R., Nash, A. A., Webster, R. G., \& Taylor, G. L. 2014. Prevention of influenza by targeting host receptors using engineered proteins. Proceedings of the National Academy of Sciences of the United States of America 111(17): 6401-6406.

Costa, S., Almeida, A., Castro, A., \& Domingues, L. 2014. Fusion tags for protein solubility, purification and immunogenicity in Escherichia coli: the novel Fh8 system. Frontiers in Microbiology 5(63): 1-20.

De Lencastre Novaes, L. C., Mazzola, P. G., Pessoa, A., \& Penna, T. C. V. 2011. Citrate and phosphate influence on green fluorescent protein thermal stability. Biotechnology Progress 27(1): 269-272.

Duan, C. J., Feng, Y. L., Cao, Q. L., Huang, M. Y., \& Feng, J. X. 2016. Identification of a novel family of carbohydratebinding modules with broad ligand specificity. Scientific Reports 6(19392): 1-8.

Finkelstein, R. A. 1996. Cholera, Vibrio cholerae O1 and O139, and 
Other Pathogenic Vibrios. (S. Baron, Ed.), Medical Microbiology (4th Editio). Galveston, Texas: University of Texas Medical Branch.

Formaneck, M. S., Ma, L., \& Cui, Q. 2006. Effects of temperature and salt concentration on the structural stability of human lymphotactin: Insights from molecular simulations. Journal of the American Chemical Society 128(29): 9506-9517.

Guenther, I., Zolkiewski, M., \& Kedzierska-Mieszkowska, S. 2012. Cooperation between two $\mathrm{ClpB}$ isoforms enhances the recovery of the recombinant $\beta$-galactosidase from inclusion bodies. Biochemical and Biophysical Research Communications, 426(4): 596-600.

Guillén, D., Sánchez, S., \& Rodríguez-Sanoja, R. 2010. Carbohydrate-binding domains: Multiplicity of biological roles. Applied Microbiology and Biotechnology 85(5): 1241-1249.

Hoell, I. A., Klemsdal, S. S., Vaaje-Kolstad, G., Horn, S. J., \& Eijsink, V. G. H. 2005. Overexpression and characterization of a novel chitinase from Trichoderma atroviride strain P1. Biochimica et Biophysica Acta - Proteins and Proteomics, 1748(2): 180-190.

Islam, M. S., Aryasomayajula, A., \& Selvaganapathy, P. R. 2017. A review on macroscale and microscale cell lysis methods. Micromachines 8(83): 1-27.

Jevševar, S., Gaberc-Porekar, V., Fonda, I., Podobnik, B., Grdadolnik, J., \& Menart, V. 2005. Production of nonclassical inclusion bodies from which correctly folded protein can be extracted. Biotechnology Progress 21(2): 632639.

Kardinahl, S., Anemuller, S., \& Schafer, G. 2000. The hyperthermostable $\mathrm{Fe}$-superoxide dismutase from the archaeon Acidianus ambivalens: Characterization, recombinant expression, crystallization and effects of metal exchange. Biological Chemistry 381(11): 1089-1101.

Kashani, H. H., \& Moniri, R. 2015. Expression of recombinant pet22b-lysk-cysteine/histidine-dependent amidohydrolase/peptidase bacteriophage therapeutic protein in Escherichia coli BL21 (DE3). Osong Public Health and Research Perspectives 6(4): 256-260.

Koseki, T., Mochizuki, K., Kisara, H., Miyanaga, A., Fushinobu, S., Murayama, T., \& Shiono, Y. 2010. Characterization of a chimeric enzyme comprising feruloyl esterase and family 42 carbohydrate-binding module. Applied Microbiology and Biotechnology 86(1): 155-161.

Kudou, M., Yumioka, R., Ejima, D., Arakawa, T., \& Tsumoto, K. 2011. A novel protein refolding system using lauroyl-1glutamate as a solubilizing detergent and arginine as a folding assisting agent. Protein Expression and Purification 75(1): 46-54.

Lin, H. H., Han, L. Y., Zhang, H. L., Zheng, C. J., Xie, B., Cao, Z. W., \& Chen, Y. Z. 2006. Prediction of the functional class of metal-binding proteins from sequence derived physicochemical properties by support vector machine approach. BMC Bioinformatics 7(Suppl.5): 1-10.

Lis, H., \& Sharon, N. 1998. Lectins: Carbohydrate-Specific proteins that mediate cellular recognition. Chemical Reviews 98(2): 637-674.

Liu, S., \& Ding, S. 2016. Replacement of carbohydrate binding modules improves acetyl xylan esterase activity and its synergistic hydrolysis of different substrates with xylanase. BMC Biotechnology 16(73): 1-13.

Lu, H., Luo, H., Shi, P., Huang, H., Meng, K., Yang, P., \& Yao, B. 2014. A novel thermophilic endo- $\beta-1,4-m a n n a n a s e$ from Aspergillus nidulans XZ3: Functional roles of carbohydratebinding module and Thr/Ser-rich linker region. Applied Microbiology and Biotechnology 98(5): 2155-2163.

Malik, A. 2016. Protein fusion tags for efficient expression and purification of recombinant proteins in the periplasmic space of E. coli. 3 Biotech 6(1): 44-50.
Mandal, S., \& Mandal, M. 2014. Vibrio: Vibrio cholerae. In C. A. Batt \& M. Lou Tortorello (Eds.), Encyclopedia of Food Microbiology (2nd Edition, pp. 708-716). Oxford, UKm: Elsevier.

Massiah, M. A., Wright, K. M., \& Du, H. 2016. Obtaining soluble folded proteins from inclusion bodies using sarkosyl, triton X-100, and CHAPS: Application to LB and M9 minimal media. Current Protocols in Protein Science 83: 6.13.1-6.13.24.

Moustafa, I., Connaris, H., Taylor, M., Zaitsev, V., Wilson, J. C., Kiefel, M. J., ... Taylor, G. 2004. Sialic acid recognition by Vibrio cholerae neuraminidase. Journal of Biological Chemistry 279(39): 40819-40826.

Niesen, F., Berglund, H., \& Vedadi, M. 2007. The use of differential scanning fluorimetry to detect ligand interactions that promote protein stability. Nature Protocols, 2(9): 2212-2221.

Palm-Espling, M. E., Niemiec, M. S., \& Wittung-Stafshede, P. 2012. Role of metal in folding and stability of copper proteins in vitro. Biochimica et Biophysica Acta - Molecular Cell Research 1823(9): 1594-1603.

Pereira, J. C., Giese, E. C., Moretti, M. M. S., Santos Gomes, A. C., Perrone, O. M., Boscolo, M., da Silva, R., Gomes, E., \& Martins, D. A. B. 2017. Effect of metal ions, chemical agents and organic compounds on lignocellulytic enzyme activities. Intech Open.

Peternel, Š., Grdadolnik, J., Gaberc-Porekar, V., \& Komel, R. 2008. Engineering inclusion bodies for non denaturing extraction of functional proteins. Microbial Cell Factories 7(34): 1-9.

Ribeiro, J. P., Pau, W., Pifferi, C., Renaudet, O., Varrot, A., Mahal, L. K., \& Imberty, A. 2016. Characterization of a highaffinity sialic acid-specific CBM40 from Clostridium perfringens and engineering of a divalent form. Biochemical Journal 473(14): 2109-2118.

Schlager, B., Straessle, A., \& Hafen, E. 2012. Use of anionic denaturing detergents to purify insoluble proteins after overexpression. BMC Biotechnology 12(95): 1-7.

Singh, A., Upadhyay, V., Upadhyay, A. K., Singh, S. M., \& Panda, A. K. 2015. Protein recovery from inclusion bodies of Eschericbia coli using mild solubilization process. Microbial Cell Factories 14(41): 1-10.

Singhvi, P., Sanaja, A., Srichandan, S., \& Panda, A. K. 2020. Bacterial inclusion bodies: A treasure trove of bioactive proteins. Trends in Biotechnology 38(5): 474-486.

Sissi, C., \& Palumbo, M. 2009. Effects of magnesium and related divalent metal ions in topoisomerase structure and function. Nucleic Acids Research 37(3): 702-711.

Sockolosky, J. T., \& Szoka, F. C. 2013. Periplasmic production via the pET expression system of soluble, bioactive human growth hormone. Protein Expression and Purification 87(2): 129-135.

Szymczyk, K., Zdziennicka, A., \& Jańczuk, B. 2018. Adsorption and aggregation properties of some polysorbates at different Temperatures. Journal of Solution Chemistry 47(11): 1824-1840.

Tang, J. Y. H., \& Sudin, N. S. 2018. Detection, isolation and antibiotic testing of Vibrio cholerae in seafood. Journal of Agrobiotechnology 9(1): 50-57.

Teh, C. S. J., Suhaili, Z., Lim, K. T., Khamaruddin, M. A., Yahya, F., Sajili, M. H., Yeo, C. C., \& Thong, K. L. 2012. Outbreakassociated Vibrio cholerae genotypes with identical pulsotypes, Malaysia, 2009. Emerging Infectious Diseases 18(7), $1177-1179$.

Upadhyay, A. K., Singh, A., Mukherjee, K. J., \& Panda, A. K. 2014. Refolding and purification of recombinant L-asparaginase from inclusion bodies of $E$. coli into active tetrameric protein. Frontiers in Microbiology 5(486): 1-10.

Villalonga, M. L., Reyes, G., \& Villalonga, R. 2004. Metal-induced stabilization of trypsin modified with $\alpha$-oxoglutaric acid. 
Biotechnology Letters 26(3): 209-212.

Walter, S., \& Buchner, J. 2002. Molecular Chaperones-Cellular Machines for Protein Folding. Angewandte Chemie International Edition 41(7): 1098-1113.

Woo, H. S., Kim, D. W., Curtis-Long, M. J., Lee, B. W., Lee, J. H., Kim, J. Y., Kang, J. E., \& Park, K. H. 2011. Potent inhibition of bacterial neuraminidase activity by pterocarpans isolated from the roots of Lespedeza bicolor. Bioorganic and Medicinal Chemistry Letters 21(20): 6100-6103.

Yoon, S., Kim, S., \& Kim, J. 2010. Secretory production of recombinant proteins in Escherichia coli. Recent Patents on Biotechnology 4(1): 23-29.

Zbacnik, T. J., Holcomb, R. E., Katayama, D. S., Murphy, B. M., Payne, R. W., Coccaro, R. C., Evans, G. J., Matsuura, J. E., Henry, C. S., \& Manning, M. C. 2017. Role of Buffers in Protein Formulations. Journal of Pharmaceutical Sciences 106(3): 713-733.

Zeng, J., Gao, X., Dai, Z., Tang, B., \& Tang, X. F. 2014. Effects of metal ions on stability and activity of hyperthermophilic pyrolysin and further stabilization of this enzyme by modification of a Ca2+-binding site. Applied and Environmental Microbiology 80(9): 2763-2772.

Zhang, Z., Tang, L., Bao, M., Liu, Z., Yu, W., \& Han, F. 2020. Functional characterization of Carbohydrate-Binding Modules in a new alginate lyase, TsAly $7 \mathrm{~B}$, from Thalassomonas sp. LD5. Marine Drugs 18(25):1-10.

Zhou, H. X., \& Pang, X. 2018. Electrostatic interactions in protein structure, folding, binding, and condensation. Chemical Reviews 118(4): 1691-1741. 